\title{
PENERAPAN CUSTOMER RELATIONSHIP MANAGEMENT MELALUI MEDIA SOSIAL TERHADAP KINERJA BISNIS : KOMPETENSI SOSIAL SEBAGAI VARIABEL MODERASI
}

\author{
Marshel Erastus Hariyanto ${ }^{1}$ dan Lydiawati Soelaiman ${ }^{1}$ \\ Program Studi Manajemen, Fakultas Ekonomi dan Bisnis, Universitas Tarumanagara Jakarta \\ Email : marshel.115172001@stu.untar.ac.id
}

\begin{abstract}
The purpose of this study was to determine whether there is a positive effect on the use of social media for Customer Relationship Management (CRM) as an independent variable and social competency as a moderating variable on the business performance of MSMEs in Jakarta. The research design used is descriptive research, the sample used in this study nonprobability sampling. This study collect data by distributing questionnaires to 42 MSMEs in Jakarta, the results of this study indicate that the use of social media for CRM has a positive and significant effect on business performance, social competency has a positive effect on business performance and social competency is unable to moderate the effect of the use of social media for CRM on business performance.
\end{abstract}

Abstrak: Tujuan dari penelitian ini adalah untuk mengetahui apakah terdapat pengaruh positif penggunaan media sosial untuk Customer Relationship Management (CRM) sebagai variabel independen dan kompetensi sosial sebagai variabel moderasi terhadap kinerja bisnis UMKM di Jakarta. Desain penelitian yang digunakan yaitu penelitian deskriptif, sampel yang digunakan pada penelitian ini yaitu non-probability sampling. Penelitian ini mengumpulkan data dengan menyebar kuesioner kepada 42 UMKM yang ada di Jakarta, hasil dari penelitian ini menunjukkan bahwa penggunaan media sosial untuk CRM berpengaruh positif dan signifikan terhadap kinerja bisnis, kompetensi sosial berpengaruh positif terhadap kinerja bisnis dan kompetensi sosial tidak mampu memoderasi pengaruh penggunaan media sosial untuk CRM terhadap kinerja bisnis.

\section{LATAR BELAKANG}

Saat ini perusahaan harus mampu berkompetitif untuk menghadapi persaingan yang tinggi, perubahan tren konsumsi, dan semakin bervariasinya permintaan pelanggan. Kemampuan pengusaha untuk membuat dan mempertahankan kepuasan bagi pelangggan adalah kunci yang sangat penting dalam menentukan keberhasilan suatu bisnis. Untuk mencapai tujuan tersebut, penting bagi pengusaha untuk memenuhi produk dan layanan sesuai dengan kebutuhan dan keinginan. Secara khusus, praktek pemasaran ini dikenal dengan istilah Customer Relationship Management (CRM). Inti dari Customer Relationship Management bukan hanya melayani, akan tetapi karena perusahaan memiliki data konsumen, maka perusahaan harus melayani dengan lebih baik sehingga pelanggan akan menjadi loyal (Setyaleksana, Suharyono \& Yulianto, 2017). Menurut Salami (2009) CRM adalah strategi membangun dan mengelola hubungan jangka panjang dengan pelanggannya. Para peneliti telah menunjukan bahwa implementasi CRM dapat memberikan layanan yang lebih baik sesuai dengan ekspektasi pelanggan sehingga berdampak pada loyalitas pelanggan.

Indonesia saat ini telah memasuki industry 4.0, yang ditandai dengan meningkatnya konektivitas, interaksi, dan batas antara manusia, mesin dan sumber daya alam lainnya yang semakin konvergen melalui teknologi informasi dan komunikasi (Rapali \& Soelaiman, 2019). 
Pelaku UMKM perlu berpikir kreatif agar dapat beradaptasi dengan memanfaatkan teknologi informasi yang salah satunya adalah pemanfaatan media sosial (Soelaiman \& Utami, 2021). Penggunaan media sosial merupakan tren untuk memfasilitasi implementasi aktivitas CRM oleh UMKM (Malthouse, Haenlein, Skeira, Wege, \& zhang, 2013; Trainor, Andzulis, Rapp, \& Agnihotri, 2014; Woodcock, Green \& Starkey, 2011). Secara sederhana media sosial merupakan media online berbasis web yang mengubah komunikasi menjadi dialog interaktif dan hal ini merupakan kabar baik bagi kemajuan bisnis (Widyaningrum, 2016). Media sosial dirasa cocok untuk UMKM karena berbiaya rendah, hambatan partisipasi rendah, dan tingkat keterampilan teknologi yang tidak rumit untuk penggunaannya (Soelaiman \& Utami, 2021).

Dalam upaya untuk mendapatkan pelanggan, sebagai pengusaha juga perlu memiliki kemampuan berkomunikasi dengan baik agar mampu bekerja sama dengan orang lain, dapat menerima maupun menghargai pendapat atau masukan orang lain, dan dapat mengontrol emosi pribadinya secara profesional. Untuk itu, selain mengandalkan media sosial, kompetensi sosial seseorang untuk dapat berinteraksi secara efektif dengan orang lain, dan mengarah pada perilaku dan respon-respon sosial yang dimiliki oleh individu juga diperlukan (Leonardi, 2013). Kemampuan komunikasi yang baik serta dapat peka terhadap apa yang dibutuhkan oleh orang lain dan mampu memimpin merupakan hal yang perlu diperhatikan dalam upaya menjaga loyalitas pelanggan.

\section{KAJIAN TEORI}

\section{Definisi Media Sosial untuk CRM}

Menurut Cahyono, S, A (2016) penggunaan media sosial adalah situs dimana seseorang dapat membuat web page pribadi dan terhubung dengan setiap orang yang tergabung dalam media sosial yang sama untuk berbagi informasi dan berkomunikasi. Sedangkan Customer Relationship Management (CRM) menurut Tjiptono (2014) adalah proses membangun dan mengelola relasi dengan pelanggan pada level organisasional dengan jalan memahami, mengantisipasi, dan mengelola kebutuhan pelanggan berdasarkan pengetahuan yang didapatkan mengenai pelanggan, dalam rangka meningkatkan efektivitas, efesiensi dan profitabilitas organisasi. Dari beberapa definisi diatas dapat disimpulkan bahwa penggunaan media sosial untuk CRM adalah penerapan media sosial yang digunakan untuk membangun relasi dengan pelanggan-pelanggan secara mudah dan langsung melalui media sosial.

\section{Definisi Kinerja Bisnsi}

Kinerja bisnis menurut Wardoyo, P, Rusdianti, E, Purwantini, S, (2015) adalah prestasi yang dicapai oleh sebuah organisasi bisnis dan dapat dilihat hasilnya. Menurut Ferdinand (2004), kinerja bisnis merupakan faktor yang umum digunakan untuk mengukur dampak dari sebuah strategi perusahaan dalam menghadapi persaingan. Dari beberapa definisi diatas dapat disumpulkan bahwa kinerja bisnis suatu tolak ukur untuk mengukur keberhasilan suatu bisnis atau suatu organisasi yang sedang dijalankan.

\section{Definisi Kompetensi Sosial}

Kompetensi sosial adalah kemampuan untuk membangun dan memelihara hubungan kerja sama serta berinteraksi dengan orang lain dalam melaksanakan tugas sosial sebagai upaya untuk mencapai tujuan pribadi maupun tujuan organisasi (Aristarini. L, Kirya. K. I, Yulianthini, N. N, 2014). Kompetensi sosial adalah kemampuan seseorang dalam berkomunikasi, membangun relasi dan kerja sama, menerima perbedaan, memikul tanggung 
jawab, menghargai hak orang lain, serta kemampuan memberi manfaat bagi orang lain (Sumardi, 2007). Dari definisi tersebut dapat disimpulkan bahwa kompetensi sosial adalah kemampuan seseorang untuk berkomunikasi atau berinteraksi dengan orang lain guna membangun jaringan.

\section{Kaitan Antara Media Sosial untuk CRM dengan Kinerja Bisnis}

Kaitan Antara Penggunaan Media Sosial Untuk CRM dan Kinerja Bisnis mirip dengan manfaat yang diberikan CRM tradisional (Mazurencu, Mihaescu \& Niculescu-Aron, 2007; Sasvari \& Majoros, 2013). Penggunaan media sosial untuk CRM dapat mengacu pada pemanfaatan pelanggan atau pengetahuan terkait untuk memberikan produk yang relevan atau layanan kepada konsumen, sehingga dapat meningkatkan angka pelanggan dab volume penjualan. Penggunaan media sosial memberikan banyak keuntungan, karena komunikasi dilakukan secara real-time sehingga memungkinkan perusahaan untuk melakukan interaksi dengan menanggapi pelanggan lebih cepat (Charoensukmongkol.P, dan Sasatanun.P, 2017).

(H1) : Terdapat pengaruh penggunaan media sosial untuk CRM terhadap kinerja bisnis UMKM

\section{Kaitan Antara Kompetensi Sosial dengan Kinerja Bisnis}

Menurut penelitian Aziz.A, Mursityo.T.Y, dan Rachmadi, A, (2018) kompetensi sosial dari pengusaha turut mempengaruhi kinerja bisnis. Kemampuan entrepreneur dalam berinteraksi dengan para stakeholder akan mengarah pada relasional jejaring (Sidiq, A., Wijayanti, T. H., 2018).

(H2) : Terdapat pengaruh kompetensi sosial terhadap kinerja bisnis UMKM

\section{Kaitan antara Moderasi Kompetensi Sosial antara Penggunaan Media Sosial untuk CRM dengan Kinerja Bisnis}

Pengaruh dari pengunaan media sosial untuk CRM dan kinerja bisnis akan semakin kuat jika terdapat kompetensi sosial. Kompetensi sosial merupakan suatu sikap atau perilaku seseorang berkomunikasi satu sama lain dengan baik. Tetapi penelitian Charoensukmongkol.P, dan Sasatanun.P (2017) menunjukkan hal sebaliknya yaitu adanya hubungan antara intensitas penggunaan media sosial untuk CRM dan kepuasan kinerja bisnis yang lebih tinggi pada pengusaha dengan tingkat kompetensi sosial yang rendah. Hal ini dikarenakan wirausahawan yang kurang memiliki kompetensi sosial cenderung menggunakan media sosial seacara intensif untuk berinteraksi dengan pelanggan.

(H3) : Kompetensi sosial mampu memoderasi pengaruh penggunaan media sosial untuk CRM terhadap kinerja bisnis UMKM 
Penggunaan

Media Sosial

Untuk CRM

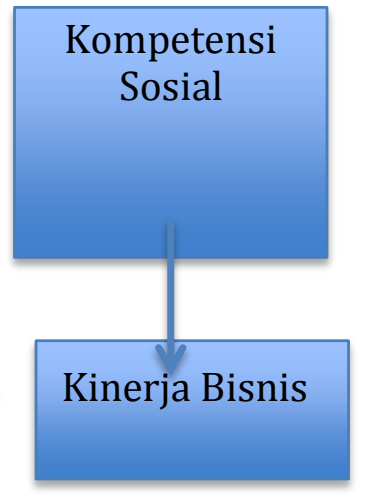

Gambar 1. Model Penelitian

\section{METODOLOGI}

Penelitian ini menggunakan desain penelitian deskriptif dan populasi yang dilibatkan dalam penelitian ini yaitu UMKM yang menggunakan media sosial yang berada di wilayah Jakarta. Pengambilan sampel menggunakan non-probability sampling dengan metode purposive sampling yang artinya tidak memberikan peluang atau kesempatan yang sama bagi setiap unsur atau anggota populasi untuk dipilih menjadi sampel. Ukuran sampel pada penelitian ini menggunakan sebanyak 42 responden.

Tabel 1. Indikator Pengukuran Variabel

\begin{tabular}{|c|c|}
\hline Variabel & Indikator \\
\hline $\begin{array}{l}\text { Penggunaan Media } \\
\text { Sosial Untuk CRM }\end{array}$ & $\begin{array}{l}\text { 1. Penggunakan media sosial untuk mengumpulkan data dari setiap } \\
\text { pelanggan } \\
\text { 2. Penggunakan media sosial untuk mengelompokan pelanggan } \\
\text { 3. Penggunaan media sosial untuk berinteraksi, berkomunikasi dan } \\
\text { bertukar pendapat dengan pelanggan. } \\
\text { 4. Penggunaan media sosial untuk memberikan informasi kepada } \\
\text { pelanggan } \\
\text { 5. Penggunaan media sosial untuk mempelajari kebutuhan pelanggan } \\
\text { 6. Penggunakan hastag ((\#) pada media sosial untuk } \\
\text { mengkategorikan produk } \\
\text { 7. Penggunaan media sosial untuk merespon permintaan khusus dari } \\
\text { pelanggan. }\end{array}$ \\
\hline Kompetensi Sosial & $\begin{array}{l}\text { 1. Memiliki hubungan interpersonal yang baik dengan pelanggan. } \\
\text { 2. Berkomunikasi dengan yakin dan antusias dalam memberikan } \\
\text { 3. layanan } \\
\text { 4. Selalu jujur dan tulus dengan pelanggan serta mitra bisnis. } \\
\text { 5. Mampalin hubungan dengan pelanggan secara teratur. } \\
\text { 6. Berbagi informasi yang berguna dengan pelanggan. }\end{array}$ \\
\hline Kinerja Bisnis & 1. Peningkatan volume penjualan \\
\hline
\end{tabular}




\section{Pertumbuhan laba \\ 3. Pengembalian investasi \\ 4. Peningkatkan kepuasan pelanggan \\ 5. Loyalitas pelanggan}

Sumber: Charoensukmongkol \& Sasatanun (2017)

Dari 42 responden mayoritas pemilik UMKM berjenis kelamin laki-laki dengan presentase $54,8 \%$, berusia $<25$ tahun dengan presentase $76,2 \%$, berdomisili di Jakarta Utara dengan presentase $57,1 \%$ dan lama berdirinya usaha yaitu 1- 3 tahun dengan presentase 78,6\% Mayoritas bidang usaha responden adalah kuliner dengan presentase $31 \%$.

Hasil analisis validitas dan reliabilitas menunjukan bahwa semua indikator memiliki nilai yang valid dikarenakan nilai AVE, Outer loadings, Cross loading memiliki nilai > 0,5. Pengukuran reliabilitas dilakukan dengan metode Cronbach Alpha, dan telah lolos uji karena Cronbach's Alpha > 0,6 maka suatu instrument dinyatakan reliabel (Chin, 1998).

Berdasarkan hasil pengujian $R$ square diperoleh nilai 0,559 yang dapat dikatakan koefisien determinasi $\left(\mathrm{R}^{2}\right)$ memilki pengaruh yang sedang. Berdasarkan hasil nilai $Q$-Square diperoleh nilai 0,137 yang menunjukan model memiliki predictive relevance. Sedangkan hasil perhitungan Goodness of fit (GoF) sebesar 0,609 maka dapat disimpulkan bahwa model yang digunakan pada penelitian ini tergolong besar.

Tabel 3. Hasil Uji hipotesis (T- statistic)

\begin{tabular}{|l|l|l|l|l|}
\hline \multicolumn{1}{|c|}{ Variabel } & \multicolumn{1}{|c|}{$\begin{array}{c}\text { Original } \\
\text { Sample }\end{array}$} & T-Statistic & P-values & Keterangan \\
\hline $\begin{array}{l}\text { Penggunaan Media Sosial } \\
\text { Untuk CRM } \rightarrow \text { Kinerja } \\
\text { Bisnis }\end{array}$ & 0,503 & 2,174 & 0,030 & Signifikan \\
\hline $\begin{array}{l}\text { Kompetensi Sosial } \rightarrow \\
\text { Kinerja Bisnis Sosial * }\end{array}$ & 0,001 & 0,003 & 0,998 & $\begin{array}{l}\text { Tidak } \\
\text { Signifikan }\end{array}$ \\
\hline $\begin{array}{l}\text { Kompetensi Sidak } \\
\text { Penggunaan Media Sosial } \\
\text { Untuk CRM } \rightarrow \text { Kinerja } \\
\text { Bisnis }\end{array}$ & 1,464 & 0,144 & Signifikan \\
\hline
\end{tabular}

Berdasarkan hasil path coefficients pada tabel 4.13 diatas dapat disimpulkan bahwa :

1) Variabel Penggunaan Media Sosial Untuk CRM memiliki pengaruh yang positif dan signifikan terhadap variabel Kinerja Bisnis dengan nilai original sample yaitu 0,503 dan $t$-statistic sebesar 2,174 dan $P$ values 0,030 yang artinya berpengaruh signifikan.

2) Variabel Kompetensi Sosial memiliki pengaruh yang positif tetapi tidak signifikan terhadap variabel dependen karena nilai original sample sebesar 0,001, $t$-statistic sebesar 0,003 dan $P$-values 0,998 yang artinya tidak berpengaruh signifikan.

3) Peran Moderasi dari variabel $=$ Kompetensi sosial Terhadap Variabel Penggunaan Media Sosial Untuk CRM dengan variabel Kinerja Bisnis memiliki pengaruh yang negative 
karena nilai original sample yaitu - 0,397, P-values 0,144 yang artinya tidak berpengaruh signifikan dan $t$-statistic sebesar 1,464.

\section{DISKUSI}

Berdasarkan dari hasil rekapitulasi uji hipotesis, hasil dari hipotesis 1 yang menyatakan terdapat pengaruh positif dan signifikan penggunaan media sosial untuk CRM terhadap kinerja bisnis UMKM dapat diterima. Penelitian ini sejalan dengan penelitian sebelumnya yang dilakukan oleh Aziz.. A, Mursityo.T.Y, dan Rachmadi, A (2018) dan juga penelitian Charoensukmongkol.P, dan Sasatanun.P (2017) yang menunjukkan adanya pengaruh positif antara intensitas penggunaan media sosial dengan kinerja perusahaan. Penggunaan Media Sosial Untuk CRM akan mempermudah membangun relasi dengan pelanggan.

Hasil dari hipotesis 2 yang menyatakan bahwa kompetensi sosial berpengaruh positif dan signigikan terhadap Kinerja Bisnis tidak diterima. Penelitian ini tidak sejalan dengan penelitian sebelumnya yang dilakukan oleh Aziz.A, Mursityo.T.Y, dan Rachmadi, A (2018) yang menyatakan bahwa kompetensi sosial dari pengusaha turut mempengaruhi kinerja bisnis. Hal ini dapat dikarenakan sebagian besar responden merupakan pengusaha muda yang berusia $<25$ tahun sehingga kurang mengandalkan kompetensi sosial untuk memperluas jejaring bisnisnya.

Hasil dari hipotesis 3 yaitu kompetensi sosial mampu memoderasi pengaruh penggunaan media sosial untuk CRM terhadap kinerja bisnis tidak diterima. Penelitian ini tidak sejalan dengan penelitian sebelumnya yang dilakukan oleh Charoensukmongkol.P, dan Sasatanun.P (2017) yang menemukan bahwa kompetensi sosial mampu memperkuat hubungan antara intensitas penggunaan media sosial untuk CRM dan kinerja bisnis. Pada penelitian ini UMKM cenderung untuk melakukan interaksi dengan konsumen melalui media sosial dibandingkan berhubungan langsung secara tatap muka dengan pelanggan.

\section{PENUTUP}

Berdasarkan hasil analisis maka dapat disimpulkan bahwa penggunaan media sosial untuk CRM berpengaruh positif dan signifikan terhadap kinerja Bisnis pada UMKM di Jakarta tetapi kompetensi Sosial tidak berpengaruh secara signifikan dan tidak mampu memoderasi pengaruh penggunaan media sosial untuk CRM terhadap kinerja bisnis pada UMKM di Jakarta.

Keterbatasan dalam penelitian ini adalah jumlah sampel yang sedikit dan hanya mencakup wilayah Jakarta. Selain itu, penyebaran kuesioner melalui link google form menyebabkan peneliti tidak dapat melakukan wawancara secara langsung dengan pemilik UMKM untuk menggali informasi yang lebih banyak berkaitan dengan penelitian ini. Untuk itu, disarankan untuk penelitian selanjutnya jumlah sampel diperbanyak dan memperluas wilayah pengambilan sampel. Selain itu, diharapkan dapat menambah variabel independen lain yang berpengaruh terhadap kinerja bisnis seperti orientasi pasar, kreativitas dan inovasi produk. Bagi UMKM disarankan untuk selalu menjalin hubungan dengan pelanggan dan mitra bisnis baik melalui media sosial maupun secara langsung.

\section{DAFTAR PUSTAKA}


Aristarini, L., Kirya, K.I., Yulianthini, N. N. (2014). Pengaruh Pengalaman Kerja, Kompetensi Sosial Dan Motivasi Kerja Terhadap Kinerja Karyawan Pada Bagian Pemasaran PT Adira Finance Singaraja. Jurnal Manajemen, Vol.2.

Asbari, Masduki., Purwanto, A., Santoso, B. P. (20200. Pengaruh Iklim Organisasi dan Kepemimpinan Trasnformasional Terhadap Produktivitas Kerja Inovatif Pada Industri Manufaktur di Pati Jawa Tengah. Jurnal Produktivitas 7, Vol.7, No,1.

Aziz, Abdul., Mursityo, T, Y,. \& Rachmadi, A. (2018). Analisis Pengunaan Media Sosial Instagram dan Pengaruhnya Terhadap Business Performance Satisfaction, Jurnal Pengembangan Teknologi Informasi dan Ilmu Komputer, Vol.11, No,11

Charoensukmongkol, P \& Sasatanun, S. (2017). Social media use for CRM and business performance satisfaction : The moderating roles of social skills and social media sales intensity. Asia Pasific Management Review.

Cahyono, S, A. (2016). Pengaruh Media Sosial Terhadap Perubahan Sosial Masyarakat Di Indonesia, Vol.9, No.1.

Chin, W. W. (1998). The Partial Least Squares Approach to Structural Equation Modeling. Modern methods for business research

Ferdinand, A. (2004). Strategi Selling-In Management: Sebuah Pendekatan pemodelan Strategi. Research Paper Series.

Leonardi, T. E. (2013). Hubungan antara Kompetensi Sosial dengan Perilaku Cyberbullying yang Dilakukan oleh Remaja Usia 15-17 Tahun. Jurnal Psikologi Kepribadian dan Sosial, Vol.2, No.2.

Mazurencu, M. M., Mihaescu, C., \& Niculescu-Aron, G. I. (2007). Why should SME adopt IT enabled CRM strategy? Informatica Economica.

Malthouse, E. C., Haenlein, M., Skiera, B., Wege, E., \& Zhang, M. (2013). Managing customer relationships in the social media Era: Introducing the social CRM house. Journal of Interactive Marketing, 27 (4).

Rapali, J.A., Soelaiman, L. (2019). Pengaruh Teknologi, Organisasi, Dan Lingkungan Eksternal Terhadap Kinerja Bisnis Umkm Di Jakarta Melalui Adopsi Media Sosial Sebagai Variabel Mediasi, Jurnal Manajerial dan Kewirausahaan Vol.1,No.4

Sidiq, A., Wijayanti, T. H. (2018). Analisis Model Relasional Jejaring Sebagai Katalisator Dalam Membangun Kinerja Bisnis. Media Ekonomi dan Manajemen, Vol.33, No.1.

Soelaiman, L., Utami, A. R. (2021). Faktor-Faktor Yang Mempengaruhi Adopsi Media Sosial Instagram dan Dampaknya Terhadap Kinerja Bisnis. Jurnal Muara Ilmu Ekonomi dan Bisnis, Vol.5, No.1.

Sumardi. (2007). Password menuju sukses: Rahasia membangun sukses individu, lembaga, dan perusahaan. Jakarta: Penerbit Erlangga.

Sasvari, P., \& Majoros, Z. (2013). How microenterprises can benefit from the use of business information systems. Bahria University Journal of Information \& Communication Technology, 6 (1).

Setyaleksana, Y. B, Suharyono, Yulianto, E. (2017). Pengaruh Customer Relationship Management (CRM) Terharap Kepuasan Dan Loyalitas Pelangan. Jurnal Administrasi Bisnis, Vol.46, No.1.

Salami, Mojtaba. (2009). Impact of Customer Relationship Management (CRM). International Journal of Organitional Inovation. Vol 2 (1)

Trainor, K. J., Andzulis, J., Rapp, A., \& Agnihotri, R. (2014). Social media technology usage and customer relationship performance: A capabilities-based examination of social CRM. Journal of Business Research, 67 (6). 
Tjiptono, F. (2014). Pemasaran Jasa Prinsip, Penerapan, dan Penelitian. Yogyakarta: ANDI. Wardoyo, P, Rusdianti, E, Purwantini, S. (2015). Pengaruh Orientasi Kewirausahaan Terhadap Strategi Usaha Dan Kinerja Bisnis UMKM Di Desa Ujung-Ujung, Kec. Pabelan, Kab Semarang, Vol.5, No.1.

Widyaningrum, W. P. (2016) Peran Media Sosial Sebagai Strategi Pemasaran Pada Sewa Kostum Meiyu Aiko Malang. Al Tijarah, Vol.2, No.2.

Woodcock, N., Green, A., \& Starkey, M. (2011). Social CRM as a business strategy. Journal of Database Marketing \& Customer Strategy Management, 18(1). 